\title{
Elisabetha VINCI
}

Università degli Studi di Catania

elisabetta.vin@gmail.com

ORCID iD: https://orcid.org/0000-0003-2680-3832

Recibido: 25/03/2019 - Aceptado: 14/07/2019

Para citar este artículo / To reference this article / Para citar este artigo

Vinci, Elisabetha. "Empathy and literary reading: the case of Fräulein Else's interior monologue".

Humanidades: revista de la Universidad de Montevideo, n 6, (20|9): |33-|5|.

https://doi.org//0.25185/6.5

\section{Empathy and literary reading: the case of Fräulein Else's interior monologue}

\begin{abstract}
This contribution is aimed at analyzing how empathy is instantiated when we read works of fiction and at studying which elements can improve the consonance between characters and readers. Starting from a brief summary about empathy with regard to literary texts, the paper examines the question concerning human reception of fictional characters in order to investigate how we empathize with them through the description of some elements which foster empathy: internal focalization, interior monologue and movement description. Fräulein Else by Arthur Schnitzler will serve as case study of empathic reading.
\end{abstract}

Keywords: empathy, literature, reading, fictional characters, interior monologue. 


\title{
Empatía y lectura literaria: el caso del monólogo interior en Fräulein Else
}

\begin{abstract}
Resumen: El objetivo de esta contribución es analizar cómo la empatía se ejemplifica cuando leemos obras de ficción y estudiar qué elementos pueden mejorar la consonancia de los personajes con los lectores. Partiendo de un breve resumen sobre la empatía con respecto a los textos literarios, el trabajo examina la cuestión de la recepción humana de los personajes ficticios para investigar cómo nos identificamos con ellos a través de la descripción de algunos elementos que fomentan la empatía: la focalización interna, el monólogo interior y la descripción del movimiento. Fräulein Else de Arthur Schnitzler servirá como caso de estudio de la lectura empática.
\end{abstract}

Palabras clave: empatía, literatura, lectura, personajes de ficción, monólogo interior.

\section{Empatia e leitura literária: o caso do monólogo interior em Fräulein Else}

\begin{abstract}
Resumo: 0 objetivo dessa contribuição é analisar como a empatia é instanciada quando lemos obras de fiç̧ão e estudamos quais elementos podem melhorar a consonância dos personagens com os leitores. Com base em um breve resumo da empatia em relação aos textos literários, o artigo examina a questão da recepção humana de personagens fictícios para pesquisar como nos identificamos com eles através da descrição de alguns elementos que estimulam a empatia: o monólogo interno e a descrição do movimento. Fräulein Else, de Arthur Schnitzler, servirá como um estudo de caso da leitura empática.
\end{abstract}

Palavras chaves: empatia, literatura, leitura, personagens fictícios, monólogo interior. 


\section{Empathy and literature: a neuroscientific approach}

As we know, empathy is a concept used in several and various disciplines such as philosophy, psychology, aesthetics and arts: it is at the basis of the relation between art's production and reception. The term empathy, a translation of the German Einfüblung, since it was first theorized by Robert Vischer in the field of aesthetics, indicates the relation of the subject with objects, spaces and the participation of the self in the experience of another person, i.e. the embodied sharing of other people's feelings and emotions. In other words, empathy is always closely linked to the relationship with others, since it opens the self to another world and overcomes our personal experience in order to establish a contact with something external ${ }^{1}$. Recent neurobiological studies demonstrated the origin of empathy from a biological perspective, thanks to the discovery of a particular group of neurons: mirror neurons. The team of neuroscientists at the University of Parma, such as Vittorio Gallese and Giacomo Rizzolatti, noticed the presence in the brain of macaques of these cells which fire not only when an action is directly executed, but also when an action is observed ${ }^{2}$. Since a mirror neuron system is present also in the human brain, as demonstrated through fMRI and PET, it can be stated that people are able to simulate observed actions through their neural system. If an action is observed, our brain reacts "as if" we were directly executing that action. The neurobiologist Antonio Damasio anticipated in a certain sense the discovery of the mirror system, because he talked about an "as if loop" to explain the functioning of the simulation. The existence of mirror neurons confers a biological basis to empathy, because it explains the reason why human beings are able to understand each other: through the neural simulation which allows us to imitate the actions, we are able to understand the intentions and even the emotions associated with that action. Vittorio Gallese deepened our understanding of the functioning of the neural simulation and used the expression "embodied

1 See'Teresa Fogliani, Empatia ed emozioni (Catania: C.U.E.C.M., 2003).

2 Marco Iacoboni, I neuroni speccbio. Come capiamo ciò che fanno gli altri (Torino: Bollati Boringhieri, 2008).

3 Antonio Damasio, The Feeling of what happens. Body and Emotion in the Making of Consciousness (Wilmington: Mariner books, 2000); Antonio Damasio, Descartes' Error: Emotion, Reason, and the Human Brain (New York: G.P Putnam, 1994). 
simulation" ${ }^{\prime 4}$ to indicate the relevance of the body in this process. He indeed distinguishes between embodied and standard simulation. The latter is a voluntary imitation, while the former is an unconscious process allowing us to be in consonance with another self. The fact that simulation involves the sensory-motor system permits to claim that the relationship among people is based on what Gallese defines as "intercorporeity", because such mechanisms establish a form of identification with other people through the simulation of their bodily states. Actually, it must be highlighted that empathy involves the sharing of both neural actions, bodily states and emotional ones, for this reason Gallese used the expression "shared manifold of intersubjectivity" which allows "intersubjective communication, social imitation and ascription of intentionality" "So, neurobiological studies give us the possibility to better investigate the functioning of the human mind and to explain the origin of some phenomena that are at the basis of personal experiences. Moreover, such kind of research can provide interesting results with regard to art perception, since empathy is a fundamental element in art's appreciation, as early 20th century theoricians of Einfüblung, such as Theodor Lipps and Wilhelm Worringer, had already understood.

In recent years, indeed, important discoveries in the field of neurosciences served as tools to interpret human reception of artworks. Matching arts and neurosciences allows scientists to understand some complex brain processes which take place also during artistic creation. Furthermore, it gives an explanation to the mystery of art's reception and appreciation. For example, understanding the biological process of empathy can be useful to explain how and why we empathize not only with real persons but also with fictional characters.

The aim of this paper is indeed to examine the reaction of readers in relation to literature, and more precisely to analyse which elements allow readers to empathize with fictional characters. First of all, we must discuss how the neurobiological mirroring mechanisms activate also during reading. Reading does not imply the direct observation of actions, so it is difficult to imagine that letters, grammatical and syntactic structures allow the activation

4 See Vittorio Gallese, “The 'shared manifold' Hypothesis: From Mirror Neurons to Empathy”, J Consc Stud, 8 (2001): 33-50. Vittorio Gallese, "The Roots of Empathy: The Shared Manifold Hypothesis and the Neural Basis of Intersubjectivity", Psychopathology, 36 (2003): 171-180. Vittorio Gallese, "Dai neuroni specchio alla consonanza intenzionale. Meccanismi neurofisiologici dell'intersoggettività”, Rivista di Psicoanalisi, LIII (2007): 197-208.

5 Ibid.

6 Vittorio Gallese, "The Roots of Empathy: The Shared Manifold Hypothesis and the Neural Basis of Intersubjectivity", cit.: 177. 
of mirror neurons. Yet, written language could serve as intermediary among mental images of what we read, since the mirror system can activate by means of linguistic communication ${ }^{7}$. Moreover, Zwaan and Taylor ${ }^{8}$ highlighted how linguistic understanding is linked to body simulation, since understanding language also requires the involvement of the motor system, so that the embodied simulation works also if an action is described through language. Indeed it has been shown that action words provoke the somatotopic activation of motor and premotor cortex ${ }^{9}$. In a nutshell, through reading it is possible to enter into consonance with fictional characters, simulating their actions at neural and bodily level.

It has been demonstrated thanks to brain imaging that the same regions of the brain activate both when we imagine and when we look at a scene. Moreover, it is certain that it takes the same time to comprehend a scene actually seen, as well as to imagine the same scene ${ }^{10}$. According to Gallese ${ }^{11}$, the process of embodiment and the emotional involvement are greater in the case of reading, because readers are totally immersed in a new world. During aesthetic fruition the percipient subject frees himself/herself of the surrounding reality, so that the embodied simulation is liberated from the bond with reality, from the burden of being prepared for the challenges of everyday life. Another element must be taken into account: the position of the reader, who usually stands still in the same position, sitting in an armchair, lying comfortably on a couch or in a bed. As a result, the readers' interaction with the world is limited, since the physical stimuli are reduced, and they are engaged with the simulation of what they read. The lack of real movements increases the identification with the characters' actions, perceptions and feelings. So, emotions are instantiated in the readers through their relation with fictional characters. Moreover, as far as characters are concerned, it is important to quote the contribution of Alan Palmer, who

7 Luca Berta, "Narrazione e neuroni specchio", in Neuronarratologia. Il futuro dell'analisi, ed. Stefano Calabrese (Bologna: Archetipo Libri, 2009), 187-203.

8 Rolf A. Zwaan and Lawrence J. Taylor, "Seeing, Acting, Understanding: Motor Resonance in Language Comprehension", Journal of Experimental Psychology 135, 1 (2006): 1-11.

9 See Olaf Hauk, Ingrid Johnsrude, Friedermann Pulvermüller "Somatopic representation of action words in human motor and premotor cortex", Neuron, vol.41 (2004): 301-307.

10 See Martha J. Farah, “The Neural Bases of Mental Imagery”, Trends in Neuroscience 12, (1989): 395-399. Stephen M. Kosslyn and William L. Thompson, "Shared Mechanisms, Visual Imagery and Visual Perception: Insights from Cognitive Science”, in The Cognitive Neurosciences, ed. Michael S. Gazzaniga (Cambridge: MIT Press, 2000), 975-985. 11 Vittorio Gallese and Hannah Wojciehowski, "How Stories Make Us Feel: Toward an Embodied Narratology", California Italian Studies 2.1 (2001), http://escholarship.org/uc/item/3jg726c2 
claimed that «novel reading is mind reading» ${ }^{12}$. According to Palmer, indeed, the human brain reacts to fictional characters as if they were real people, so we are able to empathize with them both on a bodily and mental level, since we can understand their intentions and emotions, i.e. read their minds. From this perspective, the reader assumes a fundamental role in interpreting the text and the fictional characters, as already stated in the 1970s by the theories concerning the aesthetics response by Wolfgang Iser ${ }^{13}$. The literary work is closely linked to the author and the reader: «the literary work has two poles, which we might call the artistic and the aesthetic: the artistic pole is the author's text and the aesthetic is the realization accomplished by the reader $\rangle^{14}$, so there is an interaction between author, text and reader, as Herder and Schleiermacher already affirmed in the Eighteenth century ${ }^{15}$. Gambino and Pulvirenti theorized a neurohermeneutic circle ${ }^{16}$ to explain this dynamic. According to their interpretation, «the literary text functions as a dynamic device created by the author's imagination, while its stylistic, rhetoric, metaphorical and symbolic patterns enhance the reader's imaginative process within broader cognitive and cultural networks» ${ }^{17}$.

This theory perfectly conforms to recent neurobiological studies which confirm the important role of storytelling in the evolution of men, stating that the human brain is built to appreciate stories and think according to their precise grammar ${ }^{18}$. Moreover, in this perspective narration is considered to be a fundamental practice in problem solving ${ }^{19}$.

\footnotetext{
12 Alan Palmer, "Storyworlds and Groups", in Introduction to Cognitive Cultural Studies, ed. Lisa Zunshine (Baltimora: Johns Hopkins University Press, 2010), 182.

13 Wolfgang Iser, The Act of Reading: A Theory of Aesthetic Response (London: John Hopkins University Press, 1978).

14 Ibid., 16.

15 Johann Gottfried Herder, Vom Erkennen und Empfinden der menschlichen Seele. Bemerkungen und Träume (Riga: Hartknoch, 1778); Friedrich Schleiermacher, "Hermeneutik und Kritik", in Id., Sämmtliche Werke (Berlin: Reimer, 1838).

16 Federica Abramo, Renata Gambino and Grazia Pulvirenti, "Cognitive literary Anthropology and Neurohermeneutics”, Enthymema XVIII (2017): 44-62. Renata Gambino and Grazia Pulvirenti, Storie Menti Mondi. Approccio neuroermeneutico alla letteratura (Milano: Mimesis, 2018).

17 Ibid.

18 See Sara Uboldi, Neuronarratologia della finzione. Dal paleolitico al globale (Pavia: Altravista, 2018), 11.

19 David Herman, Narratologies: New Perspectives on Narrative Analysis (Columbus: Ohio State University Press, 1999).
} 


\section{Empathic readings}

In lights of the above mentioned theories, it can be affirmed that literary texts are complex devices involving the participation of readers in the meaning-making process and that reading allows empathy and embodied simulation, just as real life situations. On the basis of these arguments, the paper aims at highlighting which elements have a greater appeal on readers in order to foster empathy and identification. In the hypothesis that I now demonstrate through a case study, two elements increase fictional empathy: the description of physical movements and the use of internal focalization.

As already claimed, the body is the means through which we perceive the external world and understand other people, because neural simulation actually corresponds to a bodily simulation of actions. When we read a novel or any kind of fictional texts, we are in the presence of characters who act, move, think and feel like real individuals and with whom readers interact as if they were real. For this reason, it is possible to claim that the presence of physical actions and the description of movements made by characters activate a stronger simulation in readers, thanks to the trigger of the sensory-motor system, so that they can share actions and feelings with fictional characters. Thanks to movement descriptions readers empathize with characters and are directly immersed in the fictional world created by the mind of the author. I would like to quote Stefan Zweig's Twenty-four Hours in the Life of a Woman, a story published in 1927. In this text, there are several passages focusing on hand movements, for example:

$[\ldots]$ his face graphically and with terrible clarity illustrated that tension between pleasure and torment. His hands, those beautiful, nervous, slenderjointed hands, instinctively began to turn into preying, hunting, fleeing animal creatures again, just as they did at the gaming table. As he spoke I saw him trembling, beginning at the wrists, arching and clenching into fists, then opening up to intertwine their fingers once more. [...] I could see his fingers pouncing on the jewels and swiftly stowing them away in the hollow of his clenched hand. ${ }^{20}$ 
In the quoted passage the feeling of a young man are conveyed through his movements, so that readers perfectly understand what he feels by following his gestures and empathizing with him.

Moreover, although unaware and unconscious of the mirror neuron system, the author himself seems to give the explanation of the mirror mechanism through one of the characters. In the following passage, the main character, Mrs C., observes the above mentioned young man moving and states: «I felt it all as clearly as if my own fingers were rummaging desperately for a coin in the pockets and folds of my creased garments ${ }^{21}$. So the lady is in an unconscious way led to simulate the young man's fingers movement as if she was directly moving herself. Of course Stefan Zweig could not know modern cognitive science but, as a sensitive human being, and writer, he had already understood the empathetic mechanism inherent to humans, thus also demonstrating the important role played by literature in the representation of complex cerebral processes. This passage exploits the description of gestures, and consequently fosters empathy: according to the discoveries concerning mirror neurons and their role in literature, it can be hypothesized that readers identify with the boy replicating the nervous movement of his hands. In fact, as Mrs C., readers are in the position of "looking" through the mind's eyes at the boy, simulating the several actions accomplished by him, and understanding what is going on, because of the emotions shared through gestures, such as anguish and worry for the situation he is experiencing.

The mechanism of embodied simulation activates thanks to the relationships between fictional characters and readers. The indications inserted by authors in their literary works help the reader to enter into the story and, more precisely, into the character. As explained by the scholar Anežka Kuzmičová, the descriptions of the actions carried out by the characters allow the reader to have the impression of being with them, of being immersed in the same space and to understand their feelings:

Imagery encompasses any vicarious experiences whatsoever of what is most commonly referred to as perception, i.e. exteroception (sight, smell, taste, touch, hearing), but also proprioception (e.g. pain), and, crucially, the senses of bodily movement (the proprioceptive, or kinesthetic, senses, e.g. the senses 
of limb and organ position, velocity, effort, acceleration and partly balance and touch) 22 .

So, reading means to be transported into the story not only from an emotional point of view, but also from a cognitive and sensory-motor perspective, for we really perceive space, body and feelings differently.

The second element to take into account is focalization. The term indicates the point of view in narrative texts and was introduced in the field of narratology by Gérard Genette ${ }^{23}$. Before Genette, Percy Lubbok and Henry James had already faced the problems of point of view in literary works. In his essay The Craft of Fiction ${ }^{24}$ Lubbok distinguishes between first and third person narrations, where the latter refers to an external telling of the story. According to Lubbok, the point of view indicates the position of the narrator with regard to the story. Genette, instead, marks two categories: voice and perspective. The former refers to the relation between story and narrator (i.e. diegesis), while the latter indicates the dynamics between the object of narration and the character. In this sense, focalization belongs to the second category, because it refers to the perspective from which the story is told, in Genette's words «a restriction of the field» $»^{25}$, a selection of narrative information. Genette formulates a distinction among three kinds of focalization: zero, external, and internal. In case of the zero focalization, there is an omniscient narrator who knows more than the characters; the external focalization refers to a story told by an external narrator who knows less than the characters. As a result, he/she is not able to guess their intentions, thought and feelings. His/her role is that of following events and reporting them. The internal focalization, instead, indicates a narration filtered by just one character, that is to say that the story is told from a focal point of view corresponding to that precise character. In this case, the reader only knows about this character's impressions, emotions, opinions and cannot know anything about the others, aside from what the focal character knows. In brief, the narrator coincides with the character in question, so that we have a restricted perspective on the story.

22 Anežka Kuzmičová, "Presence in the Reading of Literary Narrative: A Case for Motor Enactment", Semiotica 189 (2012): 26.

23 Gérard Genette, Figure III. Discorso del racconto (Torino: Einaudi,1976).

24 Percy Lubbok, The Craft of Fiction (London: Jonathan Cape, 1921).

25 Gérard Genette, Narrative Discourse Revisited (Ithaca: Cornell UP, 1988), 74. 
More recent studies concerning focalization tend to override Genette's structuralist theory. Among these, we find Tatjana Jesch and Malte Stein ${ }^{26}$ and Uri Margolin ${ }^{27}$. Jesch and Stein criticize Genette, because he mixed two elements which should remain separated: "The first element is the perception of the world invented by the author through narrators and other agents also invented by the author; the second element is the regulation of narrative information within the communication between author and reader ${ }^{28}$. According to Margolin, the concept of focalization includes: data deriving from the five senses, that are perceptions and impressions about the external world; acts of mental simulation that allow the reader to place himself in the shoes of another by imagining how he/she perceives from his/her perspective; acts of recollection, that is, moments in which «an agent activates his own episodic long term memory in order to bring into mind what he experienced through the senses at some earlier time space point $[. ..] »^{29}$. Mieke $\mathrm{Bal}^{30}$ and Manfred $\mathrm{Jahn}^{31}$, instead, agree with the inclusion of acts of planning and projections of future events among the contents of focalization. According to Jahn, «any act of perception (brief or extended; real, hypothetical or fantasized) presented in whatever form (narrated, reported, quoted, or scenically represented) counts as a case of focalization $\rangle^{32}$. But what is more relevant in Jahn's theory is the claim that focalization can affect readers as it provides information about the point of view on the fictional world, so that readers perceive that world from a precise focal point:

A passage that presents objects and events as seen, perceived, or conceptualized from a specific focus-1 will, naturally and automatically, invoke a reader's adoption of (or trans-position to) this point of view and open a window defined by the perceptual, evaluative, and affective parameters that characterize the agent providing the focus- $1^{33}$.

\footnotetext{
26 Tatjana Jesch and Malte Stein, "Perspectivization and Focalization: Two Concepts - One Meaning? An Attempt at Conceptual Differentiation”, in Point of view, Perspectve, and Focalization ed. P. Hühn, W. Schmidt, J. Schönert (Berlin: de Gruyter, 2009), 59-77.

27 Uri Margolin, Focalization: Where Do We Go from Here?, in Point of view, Perspectve, and Focalization ed. P. Hühn, W. Schmidt, J. Schönert (Berlin: de Gruyter, 2009), 41-58.

28 Tatjana Jesch and Malte Stein, "Perspectivization and Focalization: Two Concepts - One Meaning? An Attempt at Conceptual Differentiation", in Point of view, Perspectve, and Focalization ed. P. Hühn, W. Schmidt, J. Schönert (Berlin: de Gruyter, 2009), 59.

29 Uri Margolin, op. cit., 48.

30 Mieke Bal, Narratology: Introduction to the Theory of Narrative (Toronto: University of Toronto Press, 1985/1997).

31 Manfred Jahn, "Windows of Focalization: Deconstructing and Reconstructing a Narratological Concept", Style 30, no 2 (1996), 241-267.

32 Ibid., 260.

33 Ibid., 265.
} 
He hypothesizes a scale of focalization consisting of four steps: zero, weak, ambient and strict focalization ${ }^{34}$. In the first case, there is no filter upon the events, so there is no focal point of view; in a text with weak focalizaton, it is possible to identify the object of focalization but not the origin of the gaze; ambient focalization allows the multiplicity of points of view on a precise object, so that readers receive information from different perspectives. In the end, the strict focalization consists in the coincidence between point of view and focalized object, so the perception is exclusively filtered by one character. This provokes a proximity between character and reader. The presence of a single point of reference allows the reader not only to follow the spatial movements of the character, but also its perceptions, for everything is filtered by a single point of view. Therefore, the perspective from which the story is told has a great importance in reader's reaction. In case of a restricted focus, it is easier for readers to empathize with fictional characters and comprehend their actions and feelings, because there is a direct access to the character's interior world.

In order to better understand the mechanism of consonance between character and reader, an analysis of Arthur Schnitzler's Fräulein Else will now be provided, since this text presents an extreme form of internal/strict focalization and many references to physical movements.

\section{The interior monologue of Fräulein Else}

Fräulein Else (1924) is one of the most famous works written by Arthur Schnitzler. It contains some of the main themes of the Schnitzlerian production, such as the criticism of the bourgeois society and its hypocrisy, the lack of authentic values, the interest for the psychology of characters. The story takes place in a few hours and is set in a hotel in San Martino di Castrozza, a popular destination for the bourgeois of the period to spend holidays. The protagonist is Else, a young naive woman who is on holidays with her aunt and her cousin. The turning point is the letter sent by her mother. It informs the girl about the bad financial situation of her father, who needs a sum of money from Mr. Dorsday, who is spending his holiday 
in the same hotel, to avoid going to jail. Else is required to beg Mr. Dorsday for money. Else is deeply disappointed because of her mother's request, since, to some extent, she abuses her daughter. The frustration increases when Else asks Dorsday for money and he accepts but fixes a condition: he wants to see her naked. From this point on, Else has to decide what is worthiest: her family's reputation or her own dignity. For this reason, she is gripped by doubts and contradictions which undermine her thoughts. Schnitzler is able to communicate the interior drama of the girl thanks to a narrative technique, the interior monologue, which he had already chosen for the story Leutnant Gust ${ }^{35}$, anticipating the English writers Virginia Woolf and James Joyce. This technique, according to the already mentioned definitions by Genette and Jahn, corresponds to an internal and strict focalization, and allows the author to express thoughts passing in the characters' minds, and consists in writing down on the page the stream of ideas, the confusion created by the simultaneity of many thoughts related to many topics and circumstances. Interior monologue can be a free stream of thoughts without logical structure or a more structured sequence of thoughts and emotions. Even if it is often assimilated to the stream of consciousness, these two forms of narrative are not exactly interchangeable, because, as anticipated, the interior monologue can be structured and rationally organized, while the stream of consciousness, as the term suggests, is the uninterrupted flow of thoughts, sensations and emotions, which have an impact on consciousness and reflect the disorder of a character's mind with the overlap of temporal levels. Both these techniques represent extreme forms of internal focalization, to use Genette's words, since they express the restricted point of view of one character. Moreover, the deep immersion in a character allows the reader to have direct access to the fictional consciousness, which becomes the only source of information concerning reality: the outer world is exclusively filtered by the subjective inner universe. To be more precise about the interior monologue of Fräulein Else, we can quote the analysis made by Dorrit Cohn, who in her book Transparent Minds, writing about the first person narrations, distinguishes between selfquoted monologues and self-narrated monologues ${ }^{36}$. The first one refers to quotation of thoughts about the past, usually introduced by phrases such as "I said to myself". The second definition, instead, refers to the use of free indirect speech in first person, and not in third as usual. Fräulein Else's

35 Arthur Schnitzler, Leutenant Gustl (Berlin: Fischer, 1901).

36 Dorrit Cohn, Transparent Minds: Narrative Modes for Presenting Consciousness in Fiction (Princeton: Princeton University Press, 1978), 161-166. 
speech belongs to a third category, the "autonomous monologue", which is a simulation of oral speech. In particular, Cohn affirms that this work by Schnitzler is a conjunction between monologue and dialogue, because there is the compresence of discourses and thoughts with a prevalence of the former.

The whole work consists indeed of the uninterrupted thoughts of Else, with the exception of a few dialogues (with her cousin Paul, his fiancee Cissy, and Mr. Dorsday) marked by a different formatting in the text ${ }^{37}$. Else's monologue shows us all her uncertainties, doubts and contradictions that go through her head. Of course it must be taken into account that in case of internal focalization the character who narrates is not always reliable, because he/she communicates his/her perception and impression of the world which often does not correspond to reality. An example of a contradiction concerns Else's idea about suicide. She often says she wants to kill herself: «I'll kill myself if he says no» ${ }^{38}$; «I'll kill myself too. This life is a degradation. It would be best to jump over that cliff and have done with it $\rangle^{39}$. But later on she changes her mind and affirms «I'm sure I can't kill myself» or «But I won't kill myself. I don't need to» ${ }^{40}$, while in the end she will actually commit suicide. Another feature of the interior monologue, as mentioned above, is the overlapping of past, present and future, which in our mind are mixed, thus creating disjointed sentences, such as the following in which we notice an alternation of verb tenses: «I'll sit down in the lounge, look magnificent in an armchair, skim the Illustrated News and the Vie Parisienne, cross my legs - no one will notice the tear below the knee. Perhaps a millionaire has just arrived... You or no one... I'll take the white shawl, it suits me» ${ }^{41}$. Then we can find a further typical thought process, the free association of ideas: «Isn't someone's playing in there? A Beethoven sonata! How can anyone play a Beethoven sonata in this place? I'm neglecting my piano playing. I should practice regularly again in Vienna. In fact, I'll start an entirely new life» ${ }^{42}$. Thanks to this technique readers more easily attribute to the character a series of abilities and emotions: the ability to formulate thoughts, to make assumptions, to enjoy a walk at dawn or observe a beautiful landscape, as in the following passage: 
What a wonderful evening! It would have been the right weather today for a trip to the Rosetta Hut. How gorgeously the Cimone towers up into the sky! We should have started at five. Of course I should have felt miserable at first, as usual. But that wears off ... There's nothing more delightful than walking in the early morning ${ }^{43}$.

Moreover, these sentences help the reader to access character's fictional world and foster embodied empathy, because they often concern bodily movements, such as crossing the legs and play the piano. The reader shares Else's embodied analysis of her situation, as his/her body simulates her tension and nervousness, for example, when she thinks about her father, and says:

Why are you doing this to me father? If only you had something to show! But to gamble it away on the Bourse - was it worth the trouble? And the thirty thousand won't help you either. For three months perhaps. But in the end he'll have to clear out. It had nearly come to that eighteen months ago. Then help came. And what will happen to us then? ${ }^{44}$

So the reader not only sees everything from the personal perspective of Else, but follows step by step what happens in the mind of the young woman and knows directly her intentions and moods without the mediation of an external voice: «It would be terrible if I hadn't got the veronal with me. Then I'd have to jump out of the window, and I certainly shouldn't have the courage to do that. But veronal... you go to sleep slowly and never wake up again» ${ }^{45}$. In the passage provided, the reader knows directly from Else what she thinks about suicide and about her fear to suffer before dying. Indeed, the technique of interior monologue gives the reader direct access to the fictional mind without any filter: readers know what happens inside the character, without the constraints usually imposed by social conventions or circumstances. As a result, it is easier to identify with the character thanks to the direct immersion in its interior world, which abolishes the distance between reader and character. 
As we anticipated, another element which fosters empathy during reading is the presence of verbs of movement, that is, the description of actions which allows to activate the sensory-motor system. In Fräulein Else there is a great quantity of movements made by the young woman which helps the reader to empathize with her. In fact, as suggested/demonstrated by neuroscientific evidences, the written description triggers first of all the creation of mental imagery (see $\ 2$ ) and, as a consequence, the activation of mirror neurons and embodied simulation. So, it can be stated that in this work there are many elements which allow the embodied simulation and, as a result, the empathy with fictional characters. The reader indeed can experience the same emotions as the character, through the bodily simulation of its actions. Let's examine some examples from Schnitzler's Fräulein Else. From the beginning of the story, we can find hints of bodily movement such as «Now I'll turn round again and wave to them. Wave and smile» ${ }^{46}$ or «I'll sit down on the window sill and read it. I must take care I don't fall out ${ }^{47}$. We can hypothesize that the motor system activates in the reader,s as if they are performing the same gestures as the character, thus triggering a strong proximity with the young woman. The reader feels what Else feels, sitting on the window ready to read her mother's letter and then, shares the young woman's emotions. As Else goes on reading, readers feel themselves more and more involved. References to Else's body, positions and sensations are copious, «My teeth are chattering» ${ }^{48}$; «Oh, how cold the back of the chair is, but it's pleasant $»^{49} ;$ «I'm lying in bed $»^{50}$; «I can't move my lips. That's why she can't hear me. I can't move». These quotations stimulate readers' sensory-motor system, since they mobilize the touch through the reference to body sensations like the cold Else feels, the movement of the teeth, the bodily experience of lying on the bed, thus favouring the embodied simulation. Moreover, the narration, filtered from the protagonist's point of view, facilitates, as anticipated, the immersion in her world. Through the simulation of the bodily state experienced by the young woman, the reader can empathize with her; language indeed acts as a mediator and allows the reader to "see the words". A strong image is that of Else's poisoning after drinking veronal: «I've taken veronal. It's running over my legs, right and left, like ants $\rangle^{51}$. Thanks to this passage readers can

\footnotetext{
46 Ibid., 8.

47 Ibid., 19.

48 Ibid., 100.

49 Ibid., 109.

50 Ibid., 135

51 Ibid., 148.
} 
understand the bodily sensation of Else in her dramatic situation and can share her confused state of mind starting by the powerful image of the ants, thus comprehending also the reasons of her extreme gesture. From this perspective, the body becomes vehicle of important information concerning the character and of emotions, sensations, feelings. As the interior monologue does, it allows to reduce the distance separating readers and fictional minds.

\section{Conclusions}

Fictional narratives have a great impact on readers as far as empathy is concerned. The pleasure we get from reading, the fondness we feel towards some characters, our consonance with them can be scientifically explained by the recent discoveries concerning empathy in narrative. The same mechanisms which allow us to empathize with real persons activate also when we are in presence of fictional characters, thus provoking a sense of proximity towards them, as if they were real. Nevertheless, there are some features that can increase and foster empathy and, as demonstrated through the case study of Fräulein Else by Arthur Schnitzler, two of them are internal focalization and the description of actions. After analyzing the importance of internal focalization, and more precisely its effect upon readers, it can be affirmed that it helps the reader to assume a specific perspective on the story that coincides with a character's point of view. In this way, it is difficult for the reader to have a personal and objective opinion about fictional events and character, because he/she only receives restricted information and is to some extent forced to agree or at least understand and justify actions carried out by the narrating character. The interior monologue, which can be defined as an extreme form of internal focalization, emphasizes this consonance, because it allows the reader to access directly the fictional mind. In this case, the reader is more inclined to empathize with the character since his/her contact with the inner world of the character is direct, without any filter. The descriptions of gestures and movements, which in Fräulein Else are numerous, have a strong effect on the reader as well, since they activate the mechanisms of embodied simulation that allow the reader, through the activation of the sensory-motor system, to reproduce the described movements, thus not only imagining, but also bodily experiencing the scenes. In addition, according to the embodiment theories, the simulation of gestures gives access to thoughts, 
intentions and emotions. Thanks to the presence of these elements, which abolish the distance between reader and character, reading literary works such as Fräulein Else fosters empathy and permits the consonance with fictional characters. As demonstrated in this contribution, some brain processes activate in both real situations and fictional ones. For this reason, an interdisciplinary approach to literature can, on the one hand, provide information about the complex functioning of the human mind, while on the other hand, it allows us to better understand the secrets of artistic fascination. Many scientists indeed are interested in investigating the reaction of the human brain to art, because this allows them to understand the functioning of our mind. At the same time, artists can reflect on artistic creation and comprehend the reasons behind our aesthetic appreciation which, to some extent, is based on universal mechanisms.

\section{Bibliography}

Abramo, Federica, Renata Gambino and Grazia Pulvirenti. "Cognitive literary Anthropology and Neurohermeneutics". Enthymema XVIII (2017): 44-62.

Bal, Mieke. Narratology: Introduction to the Theory of Narrative. Toronto: University of Toronto Press, 1985/1997.

Berta, Luca. "Narrazione e neuroni specchio". In Neuronarratologia. Il futuro dell'analisi, edited by Stefano Calabrese, 187-203. Bologna: Archetipo Libri, 2009.

Cohn, Dorrit. Transparent Minds: Narrative Modes for presenting Consciousness in Fiction. Princeton: Princeton University Press, 1978.

Damasio, Antonio. Descartes' Error: Emotion, Reason, and the Human Brain. New York: G.P Putnam, 1994.

Damasio, Antonio. The Feeling of what happens. Body and Emotion in the Making of Consciousness. Wilmington: Mariner books, 2000.

Fahra, Martha J. “The Neural Bases of Mental Imagery”. Trends in Neuroscience 12, (1989): 395-399.

Fogliani, Teresa. Empatia ed emozioni. Catania: C.U.E.C.M., 2003. 
Gallese, Vittorio. "The 'shared manifold' Hypothesis: From Mirror Neurons to Empathy”. J Consc Stud, 8 (2001): 33-50.

Gallese, Vittorio. "The Roots of Empathy: The Shared Manifold Hypothesis and the Neural Basis of Intersubjectivity". Psychopathology, 36 (2003): 171-180.

Gallese, Vittorio. "Dai neuroni specchio alla consonanza intenzionale. Meccanismi neurofisiologici dell'intersoggettività". Rivista di Psicoanalisi LIII (2007): 197-208.

Gallese, Vittorio and Hannah Wojciehowski. "How Stories Make Us Feel: Toward an Embodied Narratology". California Italian Studies 2.1 (2001), http://escholarship.org/uc/item/3jg726c2

Gambino, Renata and Grazia Pulvirenti. Storie Menti Mondi. Approccio neuroermeneutico alla letteratura. Milano: Mimesis, 2018.

Genette, Gérard. Figure III. Discorso del racconto. Torino: Einaudi, 1976.

Genette, Gérard. Narrative Discourse Revisited. Ithaca: Cornell UP, 1988.

Herder, Johann Gottfried. Vom Erkennen und Empfinden der menschlichen Seele. Bemerkungen und Träume. Riga: Hartknoch, 1778.

Herman, David. Narratologies: New Perspectives on Narrative Analysis. Columbus: Ohio State University Press, 1999.

Hauk Olaf, Ingrid, Johnsrude Ingrid and Friedermann Pulvermüller. "Somatopic representation of action words in human motor and premotor cortex". Neuron, 41, (2004): 301-307.

Iacoboni, Marco. I neuroni specchio. Come capiamo ciò che fanno gli altri. Torino: Bollati Boringhieri, 2008.

Iser, Wolfgang. The Act of Reading: A Theory of Aesthetic Response. London: John Hopkins University Press, 1978.

Jahn, Manfred. "Windows of Focalization: Deconstructing and Reconstructing a Narratological Concept”. Style 30, nº 2 (1996), 241-267.

Jahn, Manfred. "More Aspect of Focalization: Refinements and Applications". Revue des Groupes de Recherchers Anglo-Américaines de l'Université François Rabelais de Tour 21 ed. J. Pier (1999): 85-110.

Jesch, Tatjana and Malte Stein. "Perspectivization and Focalization: Two Concepts - One Meaning? An Attempt at Conceptual Differentiation”. 
In Point of view, Perspectve, and Focalization, edited by P. Hühn, W. Schmidt, J. Schönert, 59-77. Berlin: de Gruyter, 2009.

Kosslyn, Stephen M. and L. Thompson William. "Shared Mechanisms, Visual Imagery and Visual Perception: Insights from Cognitive Science". In The Cognitive Neurosciences, edited by Michael S. Gazzaniga, 975-985. Cambridge: MIT Press, 2000.

Kuzmičová, Anežka. "Presence in the Reading of Literary Narrative: A Case for Motor Enactment". Semiotica 189 (2012): 23-48.

Lubbok, Percy. The Craft of Fiction. London: Jonathan Cape, 1921.

Mar, Raymond A. and Oatley Keith. "Emotion and narrative fiction: Interactive influences before, during, and after reading". Cognition \& Emotions 25, no 5 (2011): 818-833, 824.

Margolin, Uri. "Focalization: Where Do We Go from Here?”, in Point of view, Perspectve, and Focalization edited by P. Hühn, W. Schmidt, J. Schönert, 41-58. Berlin: de Gruyter, 2009.

Palmer, Alan. "Storyworlds and Groups". In Introduction to Cognitive Cultural Studies, edited by Lisa Zunshine, 176-192. Baltimora: Johns Hopkins University Press, 2010.

Schleiermacher, Friedrich. "Hermeneutik und Kritik", in Id., Sämmtliche Werke. Berlin: Reimer, 1838.

Schnitzler, Arthur. Leutenant Gustl. Berlin: Fischer, 1901.

Schnitzler, Arthur. Fräulein Else. London: A.M. Philpot, 1925.

Uboldi, Sara. Neuronarratologia della finzione. Dal paleolitico al globale. Pavia: Altravista, 2018.

Zwaan, Rolf A. and Lawrence J. Taylor. "Seeing, Acting, Understanding: Motor Resonance in Language Comprehension". Journal of Experimental Psychology 135, no 1 (2006): 1-11.

Zweig, Stefan. Twenty-four hours in the Life of a Woman. London: Pushkin Press, 2011. 